\title{
APLIKASI MODEL MIXED INTEGER LINEAR PROGRAMMING UNTUK PENGOLAHAN DAN PENDISTRIBUSIAN IKAN PADA INDUSTRI PERIKANAN (STUDI KASUS: PT. MULTI MINA REJEKI)
}

\author{
Eman Lesmana', Badrulfalah², Bahtiar ${ }^{3}$ \\ 1,2,3 Universitas Padjadjaran \\ email:man.msie@gmail.com
}

\begin{abstract}
ABSTRAK
Permasalahan dalam tahap produksi pada sebuah perusahaan biasanya dialami dalam kegiatan pengolahan dan pengiriman produk. Kegiatan ini sering kali tidak sesuai dengan jadwal permintaan yang sudah ditetapkan sehingga perlu dibentuk perencanaan produksi. Tulisan ini membahas tentang model perencanaan produksi beberapa produk cumi-cumi yang berasal dari beberapa pemasok pada PT. Multi Mina Rejeki. Model optimisasi Mixed Integer Linear Programming diformulasikan untuk menyelesaikan masalah ini. Keadaan dan peraturan perusahaan dijadikan sebagai fungsi kendala, sedangkan fungsi tujuannya adalah minimalisasi total biaya pengeluaran. Model pada penelitian Sayedhosseini dan Ghoreyshi diformulasikan menjadi sebuah model yang sesuai dengan objek penelitian. Data yang diperoleh pada bulan Februari 2016 digunakan sebagai parameter dalam model. Model diselesaikan menggunakan metode Branch and Bound dengan alat bantu aplikasi LINGO. Hasil penelitian menunjukkan terdapat selisih total biaya rata-rata antara model MILP dengan data primer sebesar 6,840\%.
\end{abstract}

Kata kunci: Perencanaan Pengolahan dan Pengiriman, Produk Cumi-Cumi, Optimisasi, MLLP, Branch and Bound

Dikirim: 2 Mei 2018; Diterima: 17 September 2018; Dipublikasikan: 29 September 2018

Cara sitasi: Lesmana, E., Badrulfalah., dan Bahtiar. 2018. Aplikasi Model Mixed Integer Linear Programming untuk Pengolahan dan Pendistribusian Ikan pada Industri Perikanan (Studi Kasus: PT. Multi Mina Rejeki). Jurnal Teorema: Teori dan Riset Matematika. Vol 3 No 2, Hal 195-206, September 2018. 


\section{PENDAHULUAN}

Industri perikanan merupakan seluruh aktivitas yang berkaitan dengan pengelolaan dan pemanfaatan sumber daya ikan serta lingkungannya mulai dari praproduksi, produksi, penyimpanan, distribusi sampai dengan pemasaran yang dilaksanakan dalam suatu sistem bisnis perikanan. PPI Muara Angke merupakan salah satu bagian dari industri perikanan di Indonesia yang memiliki peranan dalam proses pengelolaan dan pemanfaatan hasil tangkapan laut. Sistem rantai pasok untuk hasil tangkapan laut dilakukan oleh perusahaan yang terlibat di dalam menyalurkan hasil tangkapan ke perusahaan olahan maupun langsung ke tangan konsumen. Permasalahan produksi dan distribusi hasil tangkapan laut di PPI Muara Angke dapat berupa proses pengolahan, penyimpanan, pengiriman, akses stabilitas, dan biaya. PT. Multi Mina Rejeki sebagai salah satu perusahaan distributor hasil tangkapan laut khususnya produk cumi-cumi juga mendapati masalah dalam pengolahan dan pengiriman produk cumi-cumi. Hal ini berdampak pada biaya pengeluaran perusahaan yang fluktuatif setiap periodenya. Perencanaan proses pengolahan untuk produk cumi-cumi sangat penting karena dipandang sebagai produk yang bersifat tidak tahan lama dan mudah rusak. Pengiriman seringkali terhambat oleh ketersediaan kendaraan diluar perkiraan untuk memenuhi permintaan. Perusahaan harus membuat perencanaan pengolahan dan pengiriman produk cumi-cumi yang bertujuan untuk memenuhi permintaan konsumen sekaligus meminimumkan biaya pengeluaran.

Beberapa penelitian yang telah dilakukan tentang perencanaan produksi dan distribusi terpadu untuk produk tidak tahan lama dengan konsep persediaan dan pertimbangan rute yang bertujuan meminimalkan total biaya (Sayedhosseini dan Ghoreyshi ,2014). Sedangkan Suswaini (2013) mencoba menerapkan konsep produksi dan distribusi terpadu pada rantai pasok suatu perusahaan manufaktur dengan objek beberapa pabrik, produk, pusat distribusi, dan beberapa periode dimodelkan kedalam MILP (Mixed Integer Linear Programming). Berdasarkan permasalahan tersebut, penelitian ini membahas model perencanaan produksi dan pengiriman terpadu pada rantai pasok produk cumi-cumi. Penelitian ini menggabungkan perencanaan pengolahan dan pengiriman secara terpadu pada perusahaan distributor ikan PT. Multi Mina Rejeki yang memiliki beberapa pemasok ikan, produk, dan pengiriman dalam memenuhi permintaan yang dimodelkan kedalam MILP (Mixed Integer Linear Programming).

Tujuan penelitian adalah sebagai berikut :

1. Penerapan model MILP (Mixed Integer Linear Programming) dari masalah nyata di PT. Multi Mina Rejeki.

2. Memberikan solusi alternatif sebagai upaya untuk meminimumkan total biaya pengolahan dan pengiriman produk cumi-cumi bagi PT. Multi Mina Rejeki.

\section{METODE PENELITIAN}

Metode penelitian yang digunakan adalah observasi langsung pada perusahaan distribusi ikan PT. Multi Mina Rejeki yang berlokasi di Jakarta Utara. Obyek yang diobservasi adalah proses produksi dan pendistribusian produk ikan cumi-cumi. Model yang dibentuk berdasarkan kegiatan perusahaan khususnya bagian pengolahan dan pengiriman produk cumi-cumi. Metode optimisasi menggunakan MILP (Mixed Integer Linear Programming). Model yang dibentuk hanya untuk perencanaan kegiatan pengolahan dan pengiriman produksi ikan cumi-cumi dalam satu minggu.

Dikirim: 2 Mei 2018; Diterima: 17 September 2018; Dipublikasikan: 29 September 2018

Cara sitasi: Lesmana, E., Badrulfalah., dan Bahtiar. 2018. Aplikasi Model Mixed Integer Linear Programming untuk Pengolahan dan Pendistribusian Ikan pada Industri Perikanan (Studi Kasus: PT. Multi Mina Rejeki). Jurnal Teorema: Teori dan Riset Matematika. Vol 3 No 2, Hal 195-206, September 2018. 
Metode dasar yang dapat digunakan untuk menyelesaikan permasalahan ILP adalah dengan metode Branch and Bound. Branching/percabangan dari solusi dilakukan dengan membagi seluruh bagian solusi fisibel menjadi subhimpunan yang lebih kecil. Fathoming/pemutusan masalah dilakukan secara terpisah oleh bounding/pembatasan dengan uji fathoming. Submasalah diputus/fathomed jika memenuhi salah satu uji fathoming, yaitu nilai batasan kurang dari atau sama dengan $(\leq) \boldsymbol{Z}^{*}$ untuk fungsi tujuan maksimum, uji kedua jika solusi tidak fisibel, dan uji ketiga adalah solusi optimal LP bernilai integer (jika solusi lebih optimal dari batas sebelumnya, solusi ini menjadi batas baru, dan uji 1 diterapkan kembali untuk semua submasalah yang belum diputus/fathomed dengan nilai $\boldsymbol{Z}^{*}$ yang lebih optimal) ( Hillier $L$ at all 2001 ).

Inisialisasi algoritma branch and bound adalah tetapkan $\boldsymbol{Z}^{*}=\infty$, kemudian lakukan tahap bounding, fathomming, dan uji optimalitas pada seluruh masalah. Jika tidak diputus/fathomed maka klasifikasikan masalah ini menjadi submasalah selanjutnya untuk melakukan iterasi.

Langkah-langkah untuk setiap iterasi adalah sebagai berikut:

a. Branching/percabangan. Diantara seluruh submasalah yang ada (un-fathomed), pilih satunya yang dibuat paling baru bernilai lebih besar. Diantara variabel yang dibatasi sebagai variabel integer memiliki nilai noninteger pada solusi optimal untuk masalah relaksasi LP. Buat percabangan dari titik submasalah ini untuk membuat dua submasalah baru dengan menetapkan nilai variabel berikutnya misalkan $\boldsymbol{x}^{*}$ dan $\boldsymbol{x}_{j}^{*}$ nilai pada solusi. Cabangkan titik ini dengan membuat submasalah baru dengan menambahkan fungsi kendala secara berurutan $\boldsymbol{x}_{j} \leq\left\lfloor\boldsymbol{x}_{j}^{*}\right\rfloor$ dan $\boldsymbol{x}_{j} \geq\left\lfloor\boldsymbol{x}_{j}^{*}\right\rfloor+1$. Sedangkan untuk masalah binary integer linear programming variabel yang ditetapkan secara berurutan bernilai 1 dan 0 .

b. Bounding/pembatasan. Untuk setiap submasalah baru, dapatkan batasannya dengan mengaplikasikan metode simpleks pada setiap relaksasi LP dan pembulatan kebawah pada nilai $\boldsymbol{Z}$ untuk solusi optimal yang dihasilkan.

c. Fathoming/pemutusan. Untuk setiap submasalah baru, terapkan tiga uji fathomed, dan buang submasalah yang diputus/fathomed dari uji yang dilakukan.

d. Uji optimalitas. Hentikan perhitungan jika tidak ada lagi submasalah selanjutnya, dengan incumbent yang sekarang adalah optimal.

\section{TEORI RINGKAS}

Rantai pasok adalah jaringan perusahaan-perusahaan yang secara bersama-sama bekerja untuk menciptakan dan menghantarkan suatu produk ke tangan pemakai akhir. Perusahaanperusahaan tersebut biasanya termasuk supplier, pabrik, distributor, toko atau retailer, serta perusahaan-perusahaan pendukung seperti perusahaan jasa logistik ( Kotler P 2004 ). Dalam rancangan struktur rantai pasok produk perikanan ada beberapa eselon yaitu perusahaanperusahaan yang mempunyai kepentingan yang sama, yaitu suppliers, manufacturer, distributor, retail outlets, dan customers. Proses produksi hingga distribusi produk kelautan dan perikanan di Indonesia mempunyai struktur yang sangat kompleks, melibatkan banyak pihak, diantaranya adalah nelayan, pedagang kecil, pedagang besar, pabrik, eksportir, pemerintah hingga masyarakat sebagai konsumen akhir.

Sistem produksi merupakan kumpulan dari subsistem yang saling berinteraksi dengan tujuan mentransformasi input produksi menjadi output produksi. Input produksi ini dapat berupa bahan baku, mesin, tenaga kerja, modal dan informasi. Sedangkan output produksi merupakan produk yang dihasilkan berikut sampingannya seperti limbah, informasi, dan sebagainya. Biaya produksi adalah biaya yang dikeluarkan untuk mengolah bahan baku menjadi produk selesai.

Dikirim: 2 Mei 2018; Diterima: 17 September 2018; Dipublikasikan: 29 September 2018

Cara sitasi: Lesmana, E., Badrulfalah., dan Bahtiar. 2018. Aplikasi Model Mixed Integer Linear Programming untuk Pengolahan dan Pendistribusian Ikan pada Industri Perikanan (Studi Kasus: PT. Multi Mina Rejeki). Jurnal Teorema: Teori dan Riset Matematika. Vol 3 No 2, Hal 195-206, September 2018. 
Biaya ini dikeluarkan oleh departemen produksi, yang terdiri dari biaya bahan baku, biaya tenaga kerja langsung dan biaya overhead pabrik (Pujawan I N 2005). Berdasarkan sifatnya, secara umum biaya usaha perikanan pengolahan terdiri biaya investasi, tetap, dan variabel. Sistem persediaan adalah suatu sistem untuk pengadaan barang-barang dalam memenuhi kebutuhan dimasa yang akan datang. Tujuan yang hendak dicapai dalam suatu penyelesaian masalah persediaan adalah meminimumkan biaya total persediaan yang terdiri dari biaya pesan, simpan, stockout, dan pembelian. Saluran distribusi merupakan serangkaian organisasi yang terkait dalam semua kegiatan yang digunakan untuk menyalurkan produk dan status pemilikannya dari produsen kepada konsumen. Dilihat dari panjang pendeknya rantai distribusi, saluran distribusi dikelompokan menjadi saluran distribusi langsung dan tak langsung.

Di dalam dunia usaha perikanan terdapat salah satu jenis bidang usaha, yaitu usaha perikanan pengolahan. Usaha perikanan pengolahan adalah sebuah kegiatan usaha yang bertujuan untuk meningkatkan nilai tambah yang dimiliki oleh sebuah produk perikanan.Berdasarkan sifatnya, secara umum biaya usaha terdiri dari 3 jenis, yaitu biaya investasi, biaya tetap, dan biaya variabel.

Berikut ini adalah uraian mengenai bentuk-bentuk pengeluaran yang terdapat pada jenis bidang usaha perikanan:

1. Biaya investasi, meliputi: biaya pengadaan lahan, biaya konstruksi bangunan, surat tanah pabrik, penanganan jenis ikan, dan biaya yang bersifat investasi lainnya.

2. Biaya tetap, meliputi: pembuatan SIUP (Surat ljin Usaha Perdagangan), biaya perawatan bangunan, kebersihan, upah tenaga kerja tetap, keamanan, administrasi, perbaikan fasilitas, akuntansi, humas nelayan dan lapangan, pembelian kapal,asuransi pegawai dan biaya lainnya yang tidak dipengaruhi jumlah produksi.

3. Biaya variabel, meliputi: biaya pembelian bahan baku berupa ikan, biaya pembelian bahan bakar kapal, biaya pembelian garam, biaya pembelian es, upah tenaga kerja harian, upah ABK (Anak Buah Kapal), upah nahkoda, upah kuli angkut, konsumsi, penyewaan gerobak, jaring ikan, alat pancing, penerangan, kebutuhan trip, pengepakan, asuransi produk, terpal, tangki air, pembelian air tawar, pembekalan operasi tris, tali, perlengkapan bongkar muat kapal, box ikan, bakul, perlengkapan kebersihan ikan, keamanan trip, surat pengantar produk, label produk, mobil pengangkut dan biaya lainnya yang dipengaruhi jumlah produksi.

Model permasalahan pemrogramman linear dapat dinyatakan dengan persamaan: ( Hillier 2001 ).

$$
\begin{gathered}
\text { Minimize } f\left(x_{1}, x_{2}, \ldots, x_{n}\right)=c_{1} x_{1}+c_{2} x_{2}+\cdots+c_{n} x_{n} \\
\text { subject to } a_{11} x_{1}+a_{12} x_{1}+\cdots+a_{1 n} x_{n} \leq b_{1} \\
a_{21} x_{1}+a_{22} x_{1}+\cdots+a_{2 n} x_{n} \leq b_{2} \\
\vdots \\
a_{m 1} x_{1}+a_{m 2} x_{1}+\cdots+a_{m n} x_{n} \leq b_{m} \\
x_{j} \geq 0, j=1,2,3, \ldots, n
\end{gathered}
$$

dimana $\boldsymbol{a}_{\boldsymbol{i} \boldsymbol{j}}, \boldsymbol{c}_{\boldsymbol{j}}, \boldsymbol{b}_{\boldsymbol{j}},(\boldsymbol{i}=\mathbf{1}, \mathbf{2}, \ldots, \boldsymbol{m} ; \boldsymbol{j}=\mathbf{1}, \mathbf{2}, \ldots, \boldsymbol{n})$ adalah konstanta yang diketahui, dan $\boldsymbol{x}_{\boldsymbol{j}}$ adalah variabel keputusan.

Model Pemrograman Linear terdiri atas:

1. Variabel keputusan adalah suatu komponen dalam sistem yang harus ditentukan untuk memutuskan berapa jumlah atau nilai setiap variabel yang harus diambil dalam suatu masalah.

2. Fungsi objektif merupakan fungsi linear yang merepresentasikan biaya, keuntungan, atau tujuan lain menjadi maksimum atau minimum. Koefisien biaya menunjukkan peningkatan $\boldsymbol{f}$ yang akan dihasilkan dari setiap kenaikan dalam variabel keputusan.

Dikirim: 2 Mei 2018; Diterima: 17 September 2018; Dipublikasikan: 29 September 2018

Cara sitasi: Lesmana, E., Badrulfalah., dan Bahtiar. 2018. Aplikasi Model Mixed Integer Linear Programming untuk Pengolahan dan Pendistribusian lkan pada Industri Perikanan (Studi Kasus: PT. Multi Mina Rejeki). Jurnal Teorema: Teori dan Riset Matematika. Vol 3 No 2, Hal 195-206, September 2018. 
3. Fungsi kendala merupakan persamaan atau pertidaksamaan dimana $\boldsymbol{a}_{\boldsymbol{i} \boldsymbol{j}}, \boldsymbol{i}=\mathbf{1}, \ldots, \boldsymbol{n}, \boldsymbol{j}=$ $\mathbf{1}, \ldots, \boldsymbol{n}$ disebut koefisien teknologi adalah jumlah sumber daya $\boldsymbol{i}$ yang dikonsumsi oleh masingmasing unit aktifitas $\boldsymbol{j}$ dan $\boldsymbol{b}_{\boldsymbol{i}}, \boldsymbol{i}=\mathbf{1}, \ldots, \boldsymbol{m}$ adalah jumlah sumber daya $\boldsymbol{i}$ yang tersedia untuk dialokasikan pada kegiatan dengan variabel keputusan $\boldsymbol{x}_{\boldsymbol{j}} \geq \mathbf{0}, \boldsymbol{j}=\mathbf{1}, \ldots, \boldsymbol{n}$ disebut kendala nonnegatif.

Tujuan permasalahan pemrograman linear adalah mencari solusi yang layak atau disebut feasible. Pencarian solusi permasalahan pemrograman linear dapat diselesaikan dengan metode simpleks yang memberikan algoritma untuk memeriksa solusi feaslible, dimana jika solusi optimal tidak ditemukan maka akan mencari kemungkinan solusi terdekat. Suatu permasalahan pemrograman linear yang membutuhkan hasil atau nilai berupa nilai integer merupakan permasalahan integer linear programming (ILP). Model matematika untuk ILP adalah model pemrograman linear dengan satu batasan tambahan dimana variabel harus memiliki nilai integer. Jika hanya beberapa variabel yang diperlukan untuk bernilai integer, model ini merupakan permasalahan mixed integer linear programming (MILP).

\section{LINGGO}

LINGO adalah sebuah paket program Windows yang biasa digunakan untuk mengolah kasus linear programming, integer dan quadratic dilengkapi dengan perintah yang memungkinkan memperoleh informasi, mengolah data atau memanipulasi data. Perhitungan yang digunakan pada LINGO pada dasarnya menggunakan metode simpleks untuk masalah linear programming, sedangkan untuk menyelesaikan masalah integer linear programming, integer linear programming 01, dan mixed integer linear programming software LINGO menggunakan metode Branch and Bound. LINGO yang digunakan pada penelitian ini merupakan LINGO versi 13.0 dengan lisensi LGPC3136860 / Gadjah Mada University.

Untuk menentukan nilai optimal dengan menggunakan software LINGO, diperlukan beberapa tahapan yaitu:

1. Menentukan model matematika

2. Menentukan formulasi model untuk program LINGO

3. Membaca hasil yang diperoleh oleh LINGO

Model LINGO minimal memiliki tiga syarat:

1. Memerlukan fungsi objektif

2. Variabel

3. Batasan (fungsi kendala)

Untuk pengetikan fungsi kendala ke dalam Lingo1 dan pencarian solusi dengan pilihan toolbar Solve adalah sebagai berikut:

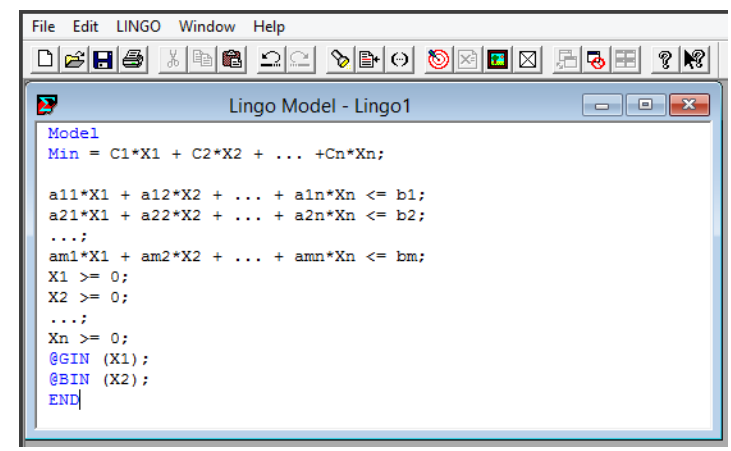

Gambar 1. Penulisan Model di LINGO

Dikirim: 2 Mei 2018; Diterima: 17 September 2018; Dipublikasikan: 29 September 2018

Cara sitasi: Lesmana, E., Badrulfalah., dan Bahtiar. 2018. Aplikasi Model Mixed Integer Linear Programming untuk Pengolahan dan Pendistribusian Ikan pada Industri Perikanan (Studi Kasus: PT. Multi Mina Rejeki). Jurnal Teorema: Teori dan Riset Matematika. Vol 3 No 2, Hal 195-206, September 2018. 


\section{HASIL DAN PEMBAHASAN}

Objek penelitian dalam penelitian ini adalah proses rantai pasok kegiatan pengolahan dan pengiriman produk cumi-cumi di PT. Multi Mina Rejeki yang dibentuk dalam perencanaan dengan memperhatikan total biaya minimum.

Proses perencanaan pengolahan dan pengiriman akan disusun kedalam model yang terdiri dari fungsi objektif, batasan-batasan, dan fungsi nonnegatif. Proses formulasi model dibentuk dengan mengembangkan model dasar dalam penelitian yang dilakukan oleh Sayedhosseini dan Ghoreyshi (2014). Pada proses produksi cumi-cumi terdiri dari beberapa kegiatan yang dapat menimbulkan biaya diantaranya kegiatan pengadaan bahan baku, proses pengemasan produk, penyimpanan produk, dan pemuatan produk siap kirim. Kegiatan tersebut menimbulkan biaya sehingga perlu ditekan agar total biaya pengeluaran minimum. Jumlah permintaan setiap minggunya perlu diperhatikan karena berpengaruh pada seluruh komponen kegiatan pengolahan dan pengiriman. Sehingga keputusan yang harus dibuat oleh perusahaan agar permintaan tercapai dan total biaya minimum diantaranya:

1. Kapan perusahaan perlu pengadaan bahan baku?

2. Berapa banyak produk yang diproduksi?

3. Berapa persediaan yang disimpan?

4. Berapa banyak produk yang dikirim?

5. Berapa kendaraan yang perlu disiapkan?

Pada penerapan model perencanaan terpadu pengolahan dan pengiriman dengan metode Mixed Integer Linear Programming diberikan asumsi sebagai berikut:

1. Permintaan dapat terpenuhi.

2. Waktu pengiriman kurang dari umur produk.

3. Harga bahan baku tidak diperhitungkan.

4. Kegiatan yang diteliti hanya pada bulan Februari 2016.

5. Tidak ada biaya tambahan yang tak terduga atau belum dianggarkan sebelumnya pada perencanaan.

6. Periode pengiriman produk terjadi setelah lima hari periode produksi.

Permasalahan perencanaan pengolahan dan pengiriman diimplementasikan dalam model Mixed Integer Linear Programming.

Variabel keputusan:

1. Penentuan pengadaan bahan baku dalam periode $t$.

$$
y_{i, k, t}=\left\{\begin{array}{c}
1, \text { jika ada pasokan dari kapal } i \text { produk } k \text { dalam periode } t \\
0 \text {, Selainnya }
\end{array}\right.
$$

2. Penentuan kuantitas produksi dalam periode $t$.

3. Penentuan tingkat persediaan dalam periode $t$.

$$
x_{i, k, t} \geq 0, \text { integer }
$$

4. Penentuan kuantitas produk yang dikirim.

$$
I_{k, t} \geq 0, \text { integer }
$$

$$
\begin{aligned}
& \text { 4. Penentuan kuantitas produk yang dikirim. } \\
& \qquad q_{k} \geq 0 \text {, integer }
\end{aligned}
$$

5. Penentuan banyaknya kendaraan untuk pengiriman.

$$
z \geq 0 \text {, integer }
$$

Tujuan utama masalah perencanaan pengolahan dan pengiriman adalah meminimumkan total biaya pengeluaran.

Dikirim: 2 Mei 2018; Diterima: 17 September 2018; Dipublikasikan: 29 September 2018

Cara sitasi: Lesmana, E., Badrulfalah., dan Bahtiar. 2018. Aplikasi Model Mixed Integer Linear Programming untuk Pengolahan dan Pendistribusian lkan pada Industri Perikanan (Studi Kasus: PT. Multi Mina Rejeki). Jurnal Teorema: Teori dan Riset Matematika. Vol 3 No 2, Hal 195-206, September 2018. 
Fungsi objektif:

$\operatorname{Min} T C=\left(\left(\sum_{i=1}^{5} \sum_{k=1}^{5} \sum_{t=1}^{5} s_{t} \cdot y_{i, k, t}\right)+\left(\sum_{i=1}^{5} \sum_{k=1}^{5} \sum_{t=1}^{T} c_{k} \cdot x_{i, k, t}\right)+\right.$
$\left.\left(\sum_{k=1}^{5} \sum_{t=1}^{5} h_{k} \cdot I_{k, t}\right)++\left((g . z)+\left(\sum_{k=1}^{5} d_{k \cdot} q_{k}\right)\right)\right)+(T F)$

(7)

Fungsi kendala yang digunakan adalah:

1. Jumlah produksi setiap kapal untuk setiap produk dalam periode $t$ tidak melebihi kapasitas produksi periode $t$. Kendala ini untuk membatasi kuantitas produksi maksimal setiap periodenya.

$$
x_{i, k, t} \leq p_{\text {max }} . y_{i, k, t} \forall i=1 \ldots 5, k=1 \ldots 5, t=1 \ldots 5
$$

2. Persediaan pada periode $t$ merupakan persediaan pada periode $t$ sebelumnya ditambah dengan jumlah produksi pada periode $t$.

$$
I_{k, t}=I_{k, t-1}+\sum_{i=1}^{5} x_{i, k, t} \forall k=1 \ldots 5, t=1 \ldots 4
$$

3. Persediaan akhir periode produksi merupakan persediaan sebelumnya ditambah produksi hari itu dikurangi kuantitas produk yang dikirim.

$$
I_{k, t+1}=I_{k, t}+\left(\sum_{i=1}^{5} x_{i, k, t}\right)-q_{k} \forall k=1 \ldots 5, t=4
$$

4. Jumlah persediaan yang disimpan tidak lebih besar dari total permintaan di periode SL (Shelf Life) berikutnya. SL (Shelf Life) merupakan umur simpan produk. Hal ini merupakan jaminan bahwa produk tidak akan pernah dibuang.

$$
I_{k, t-1} \leq I_{k, t} \leq u_{k, t} \forall k=1 \ldots 5, t=1 \ldots 5
$$

5. Kendaraan memiliki kapasitas $m$ untuk mengangkut produk. Kendala ini untuk menjamin tersedianya kendaraan.

$$
z \geq \frac{\left(\sum_{k=1}^{K} q_{k}\right)}{m}
$$

6. Setiap permintaan harus terpenuhi dalam periode pengiriman.

$$
q_{k} \geq D_{k} \forall k=1 \ldots 5
$$

\section{HASIL SIMULASI MODEL}

Setelah model pengolahan dan pengiriman diformulasikan, model diimplementasikan menggunakan data simulasi. Data simulasi yang diperoleh kemudian menjadi nilai parameter bagi koefisien biaya dan koefisien teknologi model MILP. Setelah berdiskusi dengan divisi produksi di PT. Multi Mina Rejeki maka diperoleh nilai parameter yang disajikan pada Tabel 1. Pada bagian ini model simulasi dicari solusinya menggunakan metode Branch and Bound dengan bantuan aplikasi optimisasi LINGO. 
Tabel 1. Nilai Parameter dalam Model

\begin{tabular}{|c|c|}
\hline Notasi & Nilai \\
\hline$i$ & 5 \\
\hline $\boldsymbol{k}$ & 5 \\
\hline$t$ & 5 \\
\hline$s_{t}$ & Rp.2.300.000 \\
\hline$c_{k}$ & $\begin{array}{l}\text { Produk 102: Rp.12.500, Produk 2: } \\
\text { Rp.16.000, Produk 3: } \text { Rp.14.500, } \\
\text { Produk 4: Rp.13.200, Produk 5: } \\
\text { Rp.12.000 }\end{array}$ \\
\hline $\boldsymbol{h}_{\boldsymbol{k}}$ & Rp. 2.500 \\
\hline$I_{k, t-1}$ & $\begin{array}{l}\text { Produk 102: } 245 \mathrm{Kg} \text {, Produk 2: } 180 \mathrm{Kg} \text {, } \\
\text { Produk 3: } 210 \mathrm{Kg} \text {, Produk 4: } 155 \mathrm{Kg} \text {, } \\
\text { Produk 5: } 305 \mathrm{Kg}\end{array}$ \\
\hline$T F$ & Rp.58.102.000 \\
\hline$g$ & Rp.39.100.000 \\
\hline$d_{k}$ & Rp.5.300 \\
\hline$p_{\max }$ & $1.600 \mathrm{Kg} / \mathrm{Hari}$ \\
\hline $\boldsymbol{m}$ & $28.000 \mathrm{Kg}$ \\
\hline$D_{k}$ & $\begin{array}{l}\text { Produk 102: } 9322 \mathrm{Kg} \text {, Produk 2: } 19928 \\
\mathrm{Kg} \text {, Produk 3: } 32369 \mathrm{Kg} \text {, Produk 4: } \\
11608 \mathrm{Kg} \text {, Produk 5: } 7763 \mathrm{Kg}\end{array}$ \\
\hline
\end{tabular}

Setelah mengetahui nilai parameter dilakukan pencarian solusi dari model perencanaan terpadu pengolahan dan pengiriman cumi-cumi dengan menuliskan model pada form. Setelah formula diketikkan kemudian dicari solusinya dengan memilih perintah solve atau mengklik tombol solve pada toolbar. LINGO akan mengoreksi kesalahan pada formula terlebih dahulu. Jika terjadi kesalahan dalam pengetikan (tidak dapat dibaca oleh komputer) akan muncul kotak dialog dan kursor akan menunjukkan pada baris yang salah. Pada proses penyelesaian masalah LINGO memiliki menu solve. Dengan menggunakan menu solve akan ditampilkan keterangan solusi, tipe penyelesaian, dan informasi lainnya.

Keterangan aplikasi Lingo kemudian ditampilkan dan diperoleh hasil dapat dilihat pada Gambar 2 berikut:

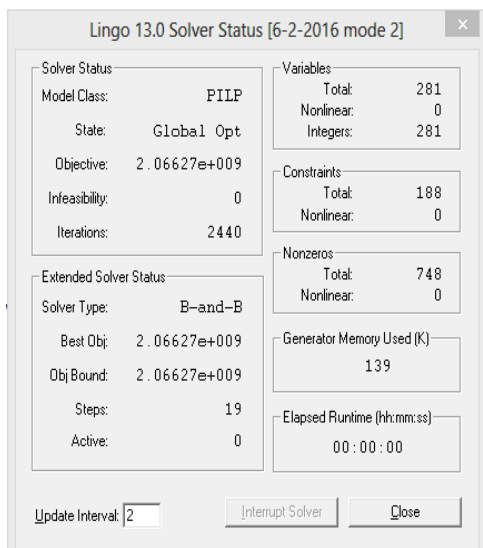

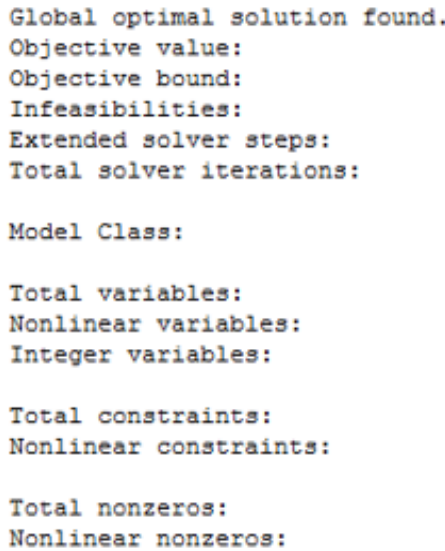

$0.2066269 \mathrm{E}+10$ $0.2066269 \mathrm{E}+10$ 0.000000 19 2440 PILP 281 0

Gambar 2. Hasil pada Aplikasi Lingo dalam file .Igr

Dikirim: 2 Mei 2018; Diterima: 17 September 2018; Dipublikasikan: 29 September 2018

Cara sitasi: Lesmana, E., Badrulfalah., dan Bahtiar. 2018. Aplikasi Model Mixed Integer Linear Programming untuk Pengolahan dan Pendistribusian lkan pada Industri Perikanan (Studi Kasus: PT. Multi Mina Rejeki). Jurnal Teorema: Teori dan Riset Matematika. Vol 3 No 2, Hal 195-206, September 2018. 
Setelah dilakukan pencarian solusi optimal menggunakan aplikasi LINGO kemudian hasil yang diperoleh dibentuk kedalam tabel perencanaan terpadu pengolahan dan pengiriman produk cumi-cumi. Variabel keputusan yang memiliki nilai optimum disusun kedalam Tabel 2 yang berisi tentang perencanaan kegiatan pengolahan dan pengiriman produk cumi-cumi selama satu minggu.

Tabel 2. Tabel perencanaan pengolahan dan pengiriman produk cumi-cumi

\begin{tabular}{|c|c|c|c|c|c|c|c|c|c|c|c|}
\hline \multirow{2}{*}{ Hari } & \multirow{2}{*}{ Kapal } & \multicolumn{5}{|c|}{ Jumlah Produksi Cumi (Kg) } & \multicolumn{5}{|c|}{ Produksi / Tidak } \\
\hline & & 1 & 2 & 3 & 4 & 5 & 1 & 2 & 3 & 4 & 5 \\
\hline \multirow{5}{*}{ Senin } & A & & & 369 & & & & & $Y$ & & \\
\hline & B & & & & & & & & & & \\
\hline & C & & & & & & & & & & \\
\hline & D & & & & & & & & & & \\
\hline & E & & & & & & & & & & \\
\hline \multirow{5}{*}{ Selasa } & A & & & 1600 & & & & & Y & & \\
\hline & B & & & 1600 & & & & & $Y$ & & \\
\hline & C & & & 1600 & & & & & $\mathrm{Y}$ & & \\
\hline & D & & & 1600 & & & & & $Y$ & & \\
\hline & E & & & 1600 & & & & & $Y$ & & \\
\hline \multirow{5}{*}{ Rabu } & A & & & 1600 & & & & & $Y$ & & \\
\hline & B & & 1600 & 1600 & & & & $\mathrm{Y}$ & $\mathrm{Y}$ & & \\
\hline & $\mathbf{C}$ & & 1600 & 1600 & & & & $Y$ & $\mathrm{Y}$ & & \\
\hline & D & & 728 & 1600 & & & & $Y$ & $\mathrm{Y}$ & & \\
\hline & $\mathbf{E}$ & & & 1600 & & & & & $Y$ & & \\
\hline \multirow{2}{*}{ Kamis } & A & 1322 & 1600 & 1600 & & & $Y$ & $\mathrm{Y}$ & $\mathrm{Y}$ & & \\
\hline & B & & 1600 & 1600 & 1600 & & & $Y$ & $Y$ & $Y$ & \\
\hline
\end{tabular}

Setelah model disimulasikan dengan data dan mampu menjelaskan permasalahan maka perencanaan pengolahan dan pengiriman produk cumi-cumi untuk permintaan pada bulan Februari 2016 dapat diterapkan dan dilihat total biaya pengeluaran optimum dengan rician pada Tabel 3 berikut:

Tabel 3. Total Biaya Perencanaan Pengolahan dan Pengiriman Produk Cumi-Cumi

\begin{tabular}{|c|c|c|c|}
\hline \multirow[b]{2}{*}{ Tgl } & \multirow[b]{2}{*}{ MILP } & Divisi Produksi & \multirow[b]{2}{*}{ Perbandingan } \\
\hline & & $\begin{array}{l}\text { PT. Multi Mina } \\
\text { Rejeki }\end{array}$ & \\
\hline $06 / 02 / 2016$ & Rp2.066.270.000 & Rp2.235.498.000 & $7,570 \%$ \\
\hline $13 / 02 / 2016$ & Rp2.035.981.000 & Rp2.203.819.000 & $7,616 \%$ \\
\hline $20 / 02 / 2016$ & Rp2.202.134.000 & Rp2.322.154.000 & $5,168 \%$ \\
\hline $27 / 02 / 2016$ & Rp2.065.171.000 & Rp2.220.754.500 & $7,006 \%$ \\
\hline
\end{tabular}

Hasil yang diperoleh merupakan solusi optimal model yang diterjemahkan ke dalam tabel perencanaan terpadu pengolahan dan pengiriman cumi-cumi. Total biaya untuk seluruh kegiatan pengolahan dan pengiriman produk cumi-cumi PT Multi Mina Rejeki dibandingkan dengan menggunakan Mixed Integer Linear Programming yaitu memiliki selisih yang berpengaruh dan dapat melakukan penghematan total biaya pengeluaran rata-rata sebesar $6,840 \%$.

Dikirim: 2 Mei 2018; Diterima: 17 September 2018; Dipublikasikan: 29 September 2018

Cara sitasi: Lesmana, E., Badrulfalah., dan Bahtiar. 2018. Aplikasi Model Mixed Integer Linear Programming untuk Pengolahan dan Pendistribusian Ikan pada Industri Perikanan (Studi Kasus: PT. Multi Mina Rejeki). Jurnal Teorema: Teori dan Riset Matematika. Vol 3 No 2, Hal 195-206, September 2018. 


\section{KESIMPULAN}

Berkaitan dengan masalah perencanaan pengolahan dan pengiriman produk cumi-cumi di PT Multi Mina Rejeki model Mixed Integer Linear Programming dengan fungsi tujuan meminimumkan total biaya pengeluaran secara keseluruhan dan fungsi kendala yang terdiri atas kondisi dan peraturan perusahaan diperoleh sebagai berikut:

$$
\begin{aligned}
& \operatorname{Min} T C=\left(\left(\sum_{i=1}^{5} \sum_{k=1}^{5} \sum_{t=1}^{5} s_{t} \cdot y_{i, k, t}\right)+\left(\sum_{i=1}^{5} \sum_{k=1}^{5} \sum_{t=1}^{T} c_{k} \cdot x_{i, k, t}\right)+\left(\sum_{k=1}^{5} \sum_{t=1}^{5} h_{k} \cdot I_{k, t}\right)\right. \\
& ++\left((g . z)+\left(\sum_{k=1}^{5} d_{k} \cdot q_{k}\right)\right)+(T F) \\
& \text { S.t } \quad x_{i, k, t} \leq p_{\max } \cdot y_{i, k, t} \forall i, k, t=1 \ldots 5 \\
& I_{k, t}=I_{k, t-1}+\sum_{i=1}^{5} x_{i, k, t} \forall k=1 \ldots 5, t=1 \ldots 4 \\
& I_{k, t+1}=I_{k, t}+\left(\sum_{i=1}^{5} x_{i, k, t}\right)-q_{k} \forall k=1 \ldots 5, t=4 \\
& I_{k, t} \leq \boldsymbol{u}_{k, t} \forall k, t=1 \ldots 5 \\
& z \geq \frac{\left(\sum_{k=1}^{5} q_{k}\right)}{28000} ; z \leq 20 \\
& q_{k} \geq D_{k} \forall k=1 \ldots 5 \\
& y_{i, k, t}=\{0,1\} ; x_{i, k, t}, I_{k, t}, q_{k}, z \geq 0 \text {,integer }
\end{aligned}
$$

Sedangkan biaya untuk seluruh kegiatan pengolahan dan pengiriman produk cumi-cumi PT Multi Mina Rejeki pada bulan Februari 2016 dibandingkan dengan penerapan model, memiliki selisih yang signifikan dan dapat melakukan penghematan total biaya pengeluaran rata-rata sebesar 6,840 $\%$.

\section{UCAPAN TERIMAKASIH}

Terima kasih kami ucapkan kepada Tim Academic Leadership ( ALG ) Unpad yang telah banyak membantu dalam pendanaan penelitian ini. 


\section{DAFTAR PUSTAKA}

Hillier, F. S., dan Lieberman, G. J. (2001). Introduction to Operations Reseacrh Seventh Edition. New York: McGraw-Hill.

Kotler, P. (2004). Manajemen Pemasaran. Jakarta : Edisi Melinium, PT. Indeks Kelompok Gramedia. Pujawan. I. N. (2005). Supply Chain Management. Surabaya: Penerbit Guna Widya.

Sayedhosseini dan Ghoreyshi. (2014). An Integrated Model for Production and Distribution Planning of Perishable Products with Inventory and Routing Considerations. Hindawi Publishing Corporation: Mathematical Problems in Engineering Volume 201410 pages. 
•206 Jurnal Teorema: Teori dan Riset Matematika Vol 3 No 2, Hal 206-206, September 2018

Dikirim: 2 Mei 2018; Diterima: 17 September 2018; Dipublikasikan: 29 September 2018

Cara sitasi: Lesmana, E., Badrulfalah., dan Bahtiar. 2018. Aplikasi Model Mixed Integer Linear Programming untuk Pengolahan dan Pendistribusian Ikan pada Industri Perikanan (Studi Kasus: PT. Multi Mina Rejeki). Jurnal Teorema: Teori dan Riset Matematika. Vol 3 No 2, Hal 195-206, September 2018. 